\title{
Development of the red algal parasite Vertebrata aterrimophila sp. nov. (Rhodomelaceae, Ceramiales) from New Zealand
}

\author{
Maren Preuss (1) ${ }^{\mathrm{a}}$ and Giuseppe C. Zuccarello (1) \\ ${ }^{a}$ School of Biological Sciences, Victoria University of Wellington, PO Box 600, Wellington, 6140, New Zealand
}

\begin{abstract}
Parasitic red algae grow only on other red algae and have over 120 described species. Developmental studies in red algal parasites are few, although they have shown that secondary pit connections formed between parasite and host and proposed that this was an important process in successful parasitism. Furthermore, it was recorded that the transfer of parasite nuclei by these secondary pit connections led to different host cell effects. We used developmental studies to reconstruct early stages and any host cell effects of a parasite on Vertebrata aterrima. A mitochondrial marker (cox1) and morphological observations (light and fluorescence microscopy) were used to describe this new red algal parasite as Vertebrata aterrimophila sp. nov. Early developmental stages show that a parasite spore connects via secondary pit connections with a pericentral host cell after cuticle penetration. Developmental observations revealed a unique connection cell that grows into a 'trunk-like' structure. Host cell transformation after infection by the parasite included apparent increases in both carbohydrate concentrations and nuclear size, as well as structural changes. Analyses of molecular phylogenies and reproductive structures indicated that the closest relative of $V$. aterrimophila is its host, V. aterrima. Our study shows a novel developmental parasite stage ('trunk-like' cell) and highlights the need for further developmental studies to investigate the range of developmental patterns and host effects in parasitic red algae.
\end{abstract}

ARTICLE HISTORY Received 29 May 2018; Revised 16 August 2018; Accepted 22 August 2018

KEYWORDS Biodiversity; cytochrome c oxidase subunit 1; infection; parasitism; phylogenetics; Rhodophyta; secondary pit connections; Vertebrata aterrima

\section{Introduction}

Parasitic red algae growing only on other red algae undergo unique development processes from spore attachment to reproductive maturity. While parasitic red algae are taxonomically quite diverse only a few studies have carefully examined parasite development, especially the early stages of infection and the cellular effects of infection on host cells (Preuss et al., 2017). An understanding of the diversity of these developmental processes is needed if any patterns, and evolutionary implications, are to be drawn.

Early in the study of these organisms, morphological characters were used to describe parasites that were closely related to their hosts (either same tribe or family) as 'adelphoparasites' and those distantly related to their hosts as 'alloparasites' (Feldmann \& Feldmann, 1958; Goff, 1982). Since then, phylogenetic studies have shown that use of the terms 'adelphoparasites' and 'alloparasites' is an extreme oversimplification as there is a range of different degrees of relatedness between parasites and hosts (Zuccarello et al., 2004; Kurihara et al., 2010; Preuss \& Zuccarello, 2018). Close relationships between parasites and hosts range from low to no genetic marker variation (e.g. Rhodophyllis parasitica M. Preuss \& Zuccarello; Preuss \& Zuccarello, 2014) to parasites being sister to host species and nested within the host genus (e.g. Gracilariophila oryzoides Setchell et H.L.Wilson; Goff et al., 1996). Distant relationships are also found between parasite and hosts ranging from parasites grouped in the same family as the hosts (e.g. Ululania stellata Apt \& Schlech; Kurihara et al., 2010) to ones found in a different family but same order as the hosts (e.g. Holmsella pachyderma (Reinsch) Sturch; Zuccarello et al., 2004). Regardless, the terms 'adelphoparasites' and 'alloparasites' have been continuously used in red algal parasites without reference to the extent of phylogenetic relationships.

In general, parasite spores attach and penetrate the host cuticle by a spore infection peg, fusing with an epidermal or subepidermal host cell (Goff \& Coleman, 1987). In some parasites the germination tube tip fuses, via a secondary pit connection, with the epidermal host cell, e.g. Dawsoniocolax bostrychiae (A.B.Joly \& Yamaguishi-Tomita) A.B.Joly \& Yamaguishi-Tomita. Sometimes this germination tube tip expands to form the first parasite cell within the host thallus before fusion, e.g. Bostrychiocolax australis Zuccarello \& J.A.West (Zuccarello \& West, 1994a). In other parasites, the germination tube divides a few times while growing into the host

CONTACT Maren Preuss Maren142@web.de

(C) 2019 British Phycological Society 
thallus before connecting to subepidermal host cells, e.g. Harveyella mirabilis (Reinsch) F.Schmitz \& Reinke (Goff, 1976). This fusion between host and parasite is through a conjunctor cell, which leads to a secondary pit connection between parasite and host cells (Goff \& Coleman, 1985) and is an important process in successful parasitism (Zuccarello et al., 2004; Preuss et al., 2017).

Secondary pit connection formation also transfers parasite organelles (e.g. nuclei, mitochondria) into host cells, and this is thought to lead to 'control' of host cells by parasite nuclei, through a process called cellular transformation (Goff \& Coleman, 1987; Salomaki \& Lane, 2014). The first demonstration of host nuclear transfer was in the parasite Leachiella pacifica Kugrens, which transferred parasite nuclei into the host cells of Polysiphonia confusa Hollenberg. These parasite nuclei did not divide or undergo DNA synthesis in the host cell (Goff \& Coleman, 1984, 1985). Another example was the transfer of parasite nuclei of Gracilariophila oryzoides into the host cells of Gracilariopsis andersonii (Grunow) E.Y.Dawson. These parasite nuclei divided and underwent DNA synthesis in host cells (Goff \& Zuccarello, 1994). Infected host cells containing parasite nuclei always showed some degree of morphological and developmental changes, including increases in starch concentration and nuclear ploidy level, plus the infection spread to surrounding host cells in some species (Goff \& Coleman, 1987; Goff \& Zuccarello, 1994).

After fusion of host and parasite cells, parasite growth can be superficial or endophytic. Superficial development is only known from the parasite Dawsoniocolax bostrychiae, where all growth is external to the host (Zuccarello \& West, 1994a). The endophytic growth in all other parasites is either by parasite cell spreading through the host thallus, such as in the parasite Leachiella pacifica Kugrens (Goff \& Coleman, 1987), or through spreading of the infection by infected host cells infecting neighbouring cells (Goff \& Zuccarello, 1994). Often, uninfected host cells, parasite cells and infected heterokaryotic cells within the host thallus get pushed upwards forming the mass of the reproductively mature parasite thallus (Goff \& Coleman, 1987; Goff \& Zuccarello, 1994).

The Ceramiales is the largest red algal order within the Florideophyceae (Yang et al., 2016) with the highest diversity of red algal parasites (Preuss et al., 2017). They occur in four families: Ceramiaceae, Daysaceae, Delesseriaceae and Rhodomelaceae (Salomaki \& Lane, 2014; Preuss et al., 2017). Most parasites in the Ceramiales are partially pigmented and grow on only one host species within the same order (Preuss et al., 2017). The family Rhodomelaceae contains many red algal parasites. The parasite Choreocolax polysiphonia Reinsch grows on Vertebrata lanosa (Linnaeus) T.A.
Christensen (Reinsch, 1875) and the parasite Leachiella pacifica grows on Polysiphonia paniculata (Montagne) J. N.Norris (as P. confusa, Goff \& Coleman, 1985) and Polysiphonia hendryi N.L.Gardner (Kugrens, 1982; Zuccarello et al., 2004). Both were first placed in the family Choreocolacaceae (order Gigartinales) (Sturch, 1926), along with Harveyella mirabilis. Later, a phylogenetic study showed these parasites had a distant relationship to their hosts but are in the Rhodomelaceae (Zuccarello et al., 2004).

In this study, we describe the development and phylogenetic placement of a new red algal parasite species from New Zealand growing on Vertebrata aterrima (Hooker \& Harvey) Kuntze. This study highlights a unique development structure in the parasite and adds to our understanding of variation in parasite development.

\section{Materials and methods}

Samples of Vertebrata aterrima, and its parasite, were collected as drift at Castlepoint $\left(40^{\circ} 54^{\prime} 08^{\prime \prime} \mathrm{S}, 176^{\circ} 13^{\prime}\right.$ $\left.43^{\prime \prime} \mathrm{E}\right)$ or growing as an epiphyte on Carpophyllum maschalocarpum (Turner) Greville at Moa Point, Wellington, New Zealand $\left(41^{\circ} 20^{\prime} 30^{\prime \prime} \mathrm{S}, 174^{\circ} 48^{\prime} 38^{\prime \prime} \mathrm{E}\right)$ from spring 2015 to spring 2016. All specimens were either pressed as herbarium vouchers, dried in silica gel, fixed in $2 \%$ glutaraldehyde in phosphate buffer $(0.1 \mathrm{M}, \mathrm{pH} 6.8)$ in $50 \%$ seawater or cultured in containers with sterile seawater.

For developmental experiments, uninfected hosts were infected by spores released from reproductively mature parasites collected in the field. Mature parasites were placed on uninfected host plants floating on a Nitex screen $(400 \mu \mathrm{m}$ mesh, Dynamic AquaSupply Ltd, Canada) in sterile seawater for one day and then removed. Hosts were removed from the Nitex screen and moved into sterile seawater. Hosts were fixed at regular time intervals and three samples of every experiment were grown for 2-3 weeks to determine successful infection.

For morphological and developmental analyses, samples were either embedded in resin following Preuss \& Zuccarello (2014) or prepared for squashing following Goff \& Coleman (1984). For squash preparations, samples were softened in saturated chloral hydrate, transferred to slides coated with Haupt's solution (Haupt, 1930) and squashed with carefully applied pressure of a soft rubber. Coverslips were removed in liquid nitrogen, then the samples were fully immersed in $70 \%$ ethanol and air dried until staining. Microscopic slides were stained with either $1.0 \mu \mathrm{g} \mathrm{ml}^{-1}$ DAPI in McIlvaine buffer ( $\mathrm{pH} 4.1$ ), $1 \%$ acidified aniline blue or $1 \%$ toluidine blue. Samples were examined using a microscope (Olympus AX-70, Tokyo, Japan) with an integrated camera (Olympus 
DP-70) and images were taking using Olympus cellSens software.

Reproductive observations of parasitic gametophytes on tetrasporophytic host plants and tetrasporophytic parasites on host gametophytes were used to confirm the outgrowth was an independent alga and not a host proliferation or bacterial infection.

For phylogenetic analyses, mature parasite thalli were selected. DNA was extracted following a modified CTAB protocol (Zuccarello \& Lokhorst, 2005) and PCR amplified using the primers, GazF1 (TCA ACA AAT CAT AAA GAT ATT GG, Saunders, 2005) and Mam2R (GTA TTA AAA TTW CKA TCW GTT A, Mamoozadeh \& Freshwater, 2011) for partial cox1. PCR conditions consisted of an initial denaturing step at $94^{\circ} \mathrm{C}$ for 5 min, followed by 35 cycles each $94^{\circ} \mathrm{C}$ for $1 \mathrm{~min}, 45^{\circ} \mathrm{C}$ for $1 \mathrm{~min}$ and $72^{\circ} \mathrm{C}$ for $1 \mathrm{~min}$, and a final extension step at $72^{\circ} \mathrm{C}$ for $10 \mathrm{~min}$. Successful amplifications were purified using ExoSAP-IT (USB product; Affymetrix, Santa Clara, California, USA) and commercially sequenced (Macrogen Inc., Seoul, Korea). Amplification of nuclear and plastid markers were unsuccessful. Sequences of the forward and reverse strands were assembled using Geneious 8.0.5 (http:// www.geneious.com, Kearse et al., 2012) and edited sequences were aligned using MAFFT alignment using default settings. Taxon sampling (Supplementary table S1) for phylogenetic analyses was selected following Díaz-Tapia et al. (2017). Bayesian analysis was performed with MrBayes v.3.2.5 (Ronquist \& Huelsenbeck, 2003) and maximum-likelihood trees (ML) with RAxML 7.2.8 (Stamatakis, 2006) following Preuss \& Zuccarello (2018).

All herbarium samples of $V$. aterrima (as Polysiphonia aterima) at the Museum of New Zealand Te Papa Tongarewa in Wellington were searched for parasites under a dissecting microscope and observed parasites were recorded.

\section{Results}

This study describes a new red algal parasite from New Zealand with a unique developmental structure. Our phylogenetic analysis indicates that the parasite shares a close relationship with its host.

\section{Developmental observations}

Released parasite spores were pigmented and spherical $(\sim 10-20 \mu \mathrm{m}$ in diameter) and attached to the host cuticle between host cells. The parasite spore developed a germination tube of up to $30 \mu \mathrm{m}$ in length (Fig. 1). Germination only occurred in the presence of the host. The germination tube connected to a pericentral host cell through a secondary pit connection (Fig. 2). After the formation of a secondary pit connection between host and parasite, a 'connection' cell developed from the germination tube and the parasite grew superficially from this cell by cell division (Fig. 3). Further secondary pit connections between the parasite 'connection' cell and several host cells were formed as the parasite grew (Fig. 4). The growing parasite 'connection' cell developed several branches that connected to the same or other host cells (Fig. 5). The 'connection' cell grew to be the largest parasite cell and was easily recognizable (Fig. 6). Sometimes two 'connection' cells were present (Fig. 7) and these cells developed into a 'trunklike' structure in mature parasite thalli (Fig. 8). Parasite cells were multinucleate, and highly connected between parasite cells (Fig. 9). Infected host cells contained many nuclei, which were almost double in size (5-10 $\mu \mathrm{m}$ diameter) in comparison to host nuclei in neighbouring non-infected host cells and parasite nuclei (3-5 $\mu \mathrm{m}$ diameter, Figs 10-11). Parasite nuclei were not distinguishable in these heterokaryotic cells. After infection, cytological changes in the infected host cells were observed and included an apparent increase in carbohydrates (Fig. 12). Infected host cells were more susceptible to plasmolysis, suggesting structural changes in these cells (Fig. 13). The infection of the parasite was highly localized and superficial, and no parasite cells were ever observed deeper in the tissue (Figs 6-8, 13). The infection did not spread to surrounding host cells, i.e. host cell was not directly connected to parasite cells (Figs 8, 13).

\section{Phylogenetic results}

Partial cox 1 sequences (726 bp) were obtained for six samples of Vertebrata aterrima and five of its parasite. Pairwise distances within parasites were $0-0.7 \%$, and between hosts $0-1.4 \%$, and between host and parasite $7.2-8.5 \%$. All parasites grouped together and were sister to its host $V$. aterrima within the genus Vertebrata and this close relationship between parasite and host was only strongly supported (Fig. 14). Our data showed that this was a new parasite and needed to be formally described.

Vertebrata aterrimophila M.Preuss \& Zuccarello, sp. nov. (Figs 15-25)

DIAGNOSIs: Thalli unpigmented to pigmented (dark brownish), 587-1500 $\mu \mathrm{m}$ in diameter with easily recognizable reproductive forms. Gametophytes dioecious. Cystocarps ovoid with ostioles and tear-drop shaped carpospores $(49-82 \mu \mathrm{m} \times 17-23 \mu \mathrm{m})$. Spermatangial branches without sterile apical cells. Tetrasporangia are tetrahedrally divided (33-43 $\mu \mathrm{m}$ $\times 30-38 \mu \mathrm{m})$ and are spirally arranged in branches. Parasitic on Vertebrata aterrima (Hooker \& Harvey) Kuntze. 

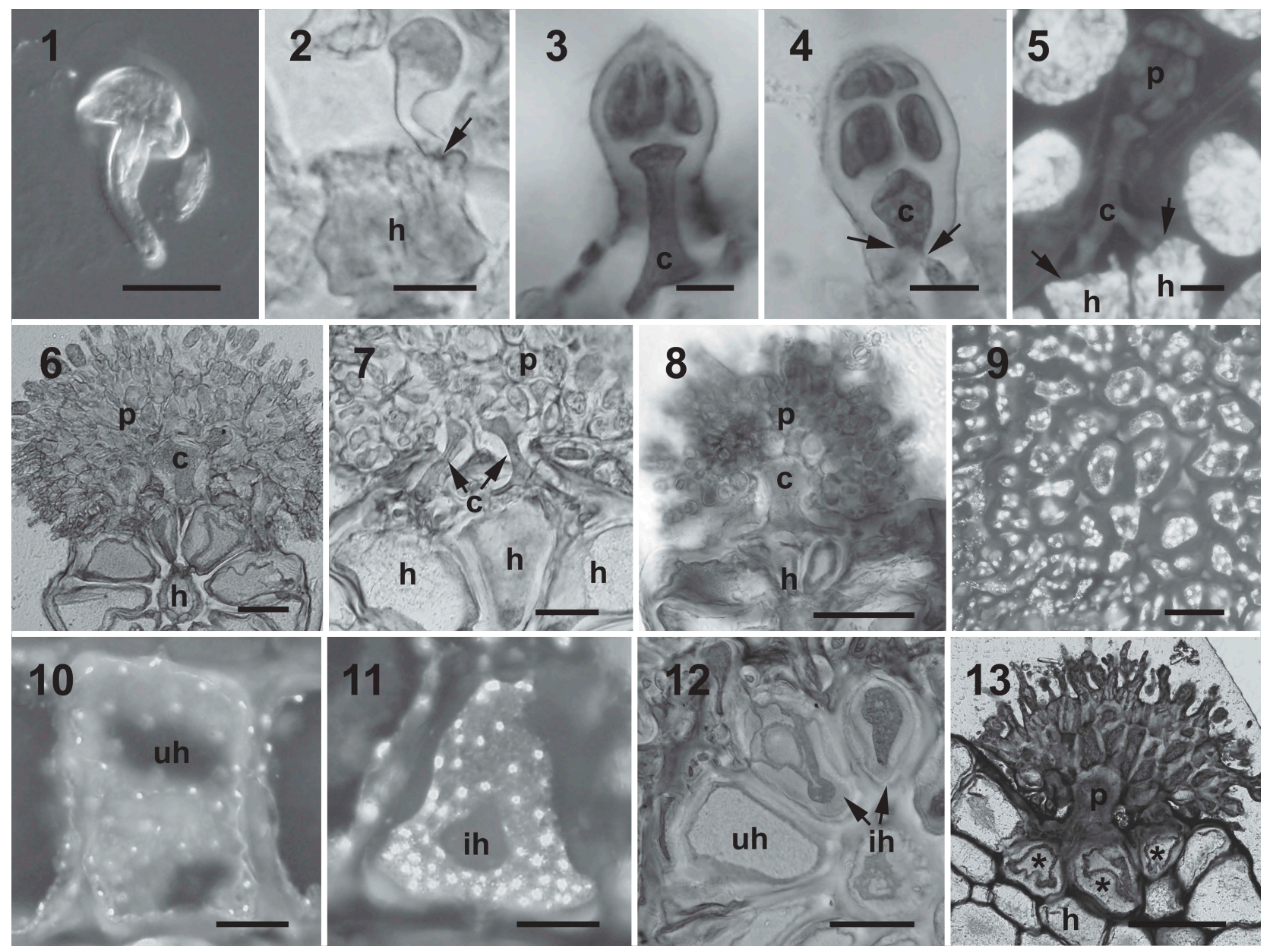

Figs 1-13. Development of Vertebrata aterrimophila on its host Vertebrata aterrima. Fig. 1. Phase contrast of germinated parasite spore, unattached to host, showing germination tube. Fig. 2. Light microscopy of germinated parasite spore which connects through a secondary pit connection (arrow) to a host cell (h). Fig. 3. Early stages of developing parasite with connection cell (c). Stained with aniline blue. Fig. 4. Parasite growing on the surface and two secondary pit connections to host cells (arrows), one out of plane of focus. Fig. 5. Autofluorescence shows non-autofluorescing parasite body (p) with large and branched connection cell (c), connecting to two host cells (arrows), plus bright autofluorescing host cells (h). Fig. 6. Parasite thallus, and cross section of host thallus, with large connection cell (c). Stained with aniline blue. Fig. 7. In some parasites (p) two connection cells (c) were observed. Aniline blue staining. Fig. 8. A mature connection cell (c), and developing parasite, resembles a 'trunk-like' connecting to various pericentral cells. Fig. 9. Multinucleate parasite cells highly connected to each other. Stained with DAPI. Fig. 10. Host nuclei in uninfected host cell (uh). Stained with DAPI. Fig 11. Host nuclei in infected host cell (ih), from same plant as Fig. 10. Stained with DAPI. Fig. 12. Infected host cells (ih) appear to have higher carbohydrate concentrations (indicated by darker aniline blue staining) than uninfected host cells (uh). Fig. 13. Infected host cells (asterisks) are more susceptible to plasmolysis and show structural changes insides cells, stained with toluidine blue. Scale bars: Figs 1-2, 5, $20 \mu \mathrm{m}$, Figs 3-4, $10 \mu \mathrm{m}$, Figs 6, 8, 12, $100 \mu \mathrm{m}$, Figs 7, 9-11, $50 \mu \mathrm{m}$, Fig. 13, $200 \mu \mathrm{m}$.

Cox1 GenBank ACCESSION NUMBers: MH670282MH670284.

HoLOTYPE: WELT A033493, collected as a parasite on Vertebrata aterrima from Moa Point, Wellington, New Zealand ( $41^{\circ} 20^{\prime} 30^{\prime \prime}$ S, $\left.174^{\circ} 48^{\prime} 38^{\prime \prime} \mathrm{E}\right)$; coll. Maren Preuss, 14/9/2015, deposited in Museum of New Zealand Te Papa Tongarewa (MH670282).

IsOTYPE: WELT A033493, deposited in Museum of New Zealand Te Papa Tongarewa (MH670283MH670283).

Type Locality: Moa Point, North Island, New Zealand.

Eтymology: The name aterrimophila refers to the parasites' affinity to its host Vertebrata aterrima.
Habitat. Vertebrata aterrimophila usually grows between branches of Vertebrata aterrima and was observed in Wellington all year round. Most infected host thalli are highly parasitized with more than 100 parasites covering the whole thallus (Fig. 15).

Pigmentation and autofluorescence. Parasite thalli can be pigmented or unpigmented and no clear pattern by location, size of parasite or reproductive stages was apparent. Small, not fully mature pigmented parasites $(\sim 150 \mu \mathrm{m}$ width $)$ show faint autofluorescence (Fig. 16).

Distribution. Te Papa collections contained 31 specimens of $V$. aterrima (as Polysiphonia aterrima) and 


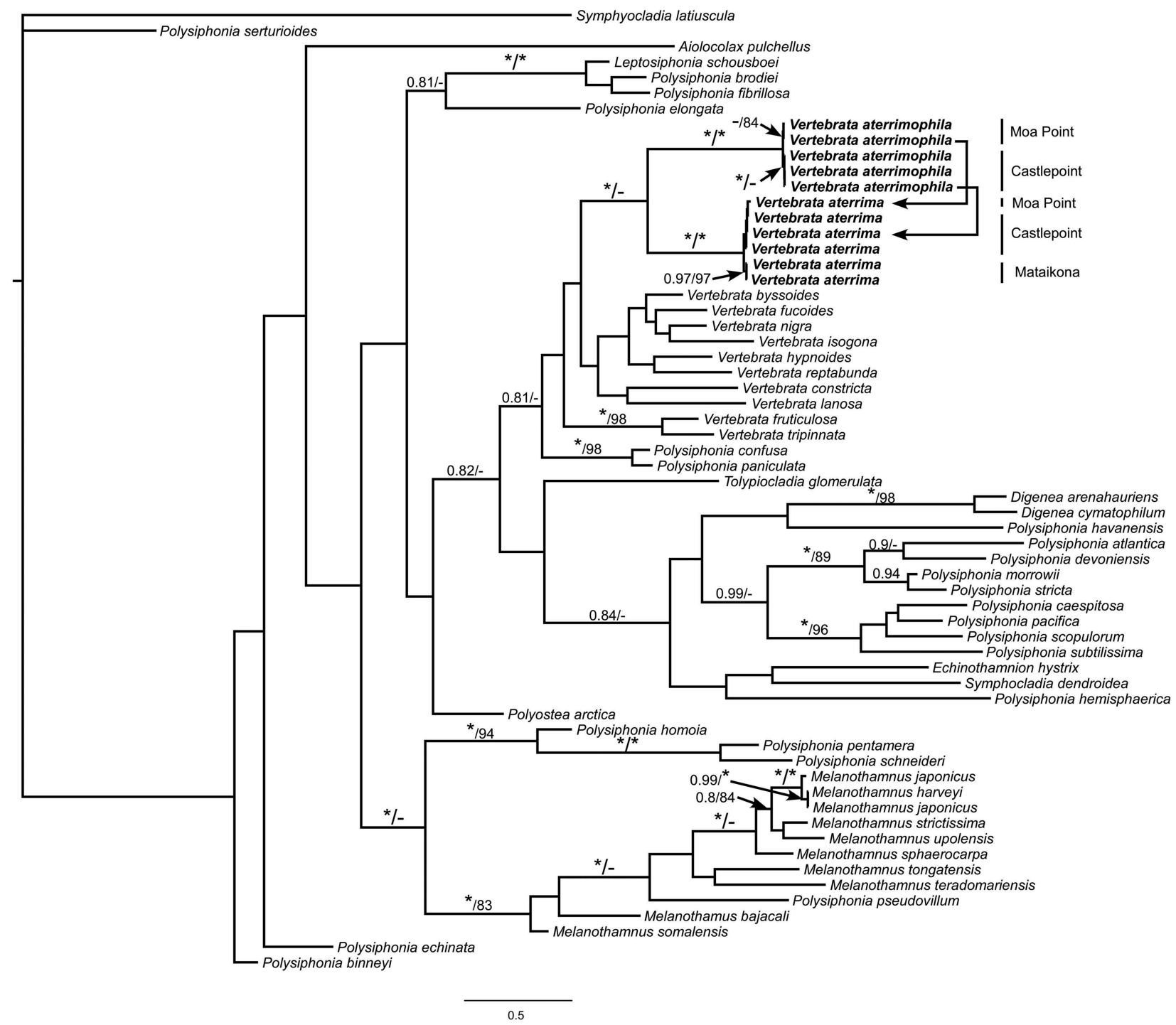

Fig. 14. Bayesian topology of partial cox1 of Vertebrata species. Vertebrata aterrima and its parasite Vertebrata aterrimophila in bold. Symphyocladia latiuscula used as outgroup. Parasite and host combinations are connected by arrows and sampling locations given. Asterisks indicate posterior probability value of $1.00 /$ bootstrap values of $100 \%$. Values $<0.80$ posterior probability and $<80 \%$ ML bootstrap not shown and indicated with a dash.

seven of those had parasites on them. The parasite was recorded from Pouawa $\left(38^{\circ} 36^{\prime} \mathrm{S}\right)$ on the east coast to Wellington $\left(41^{\circ} 20^{\prime} \mathrm{S}\right)$ in the North Island and in the Marlborough Sounds $\left(40^{\circ} 50^{\prime} \mathrm{S}\right)$ on the South Island (Supplementary table S2).

Reproductive morphology. Male, female and tetrasporophytes were observed. The parasite was dioecious. The parasite consisted of either many smooth spheres of similar sizes (female gametophyte, Fig. 17) or one rough roundish cushion with roundish branches (male gametophyte, Fig. 18) or elongate branches emanating from the thallus (tetrasporophyte; Fig. 19). Gametophytic parasites were observed growing on tetrasporophytic hosts and tetrasporophytic parasites were observed growing on gametophytic hosts.

The entire surface of mature female gametophytes was covered with ovoid, ostiolate cystocarps (Fig. 20), $\sim 160-245 \mu \mathrm{m}$ in diameter $(n=5$, Fig. 20). Carposporophytes produced elongated tear-drop shaped carpospores, $49-82 \mu \mathrm{m} \times 17-23 \mu \mathrm{m}(n=10$, Fig. 21$)$.

Mature male gametophytes were covered with spermatangial branches (Fig. 22) of $\sim 47-102 \mu \mathrm{m} \times 37-68$ $\mu \mathrm{m}$ and were lacking sterile apical cells (Fig. 23).

Sporophytic parasites were covered by tetrasporangial stichidia of $\sim 188-218 \mu \mathrm{m}$ in length and $31-37 \mu \mathrm{m}$ in diameter (Fig. 24). Tetrasporangial stichidia contained spirally arranged pigmented tetrahedrally divided tetrasporangia $\sim 33-43 \mu \mathrm{m} \times 30-38 \mu \mathrm{m}$ (Fig. 25 ).

\section{Discussion}

Our study showed some unique developmental structures of a novel parasite, and in conjunction with its phylogenetic relationship to its host Vertebrata 


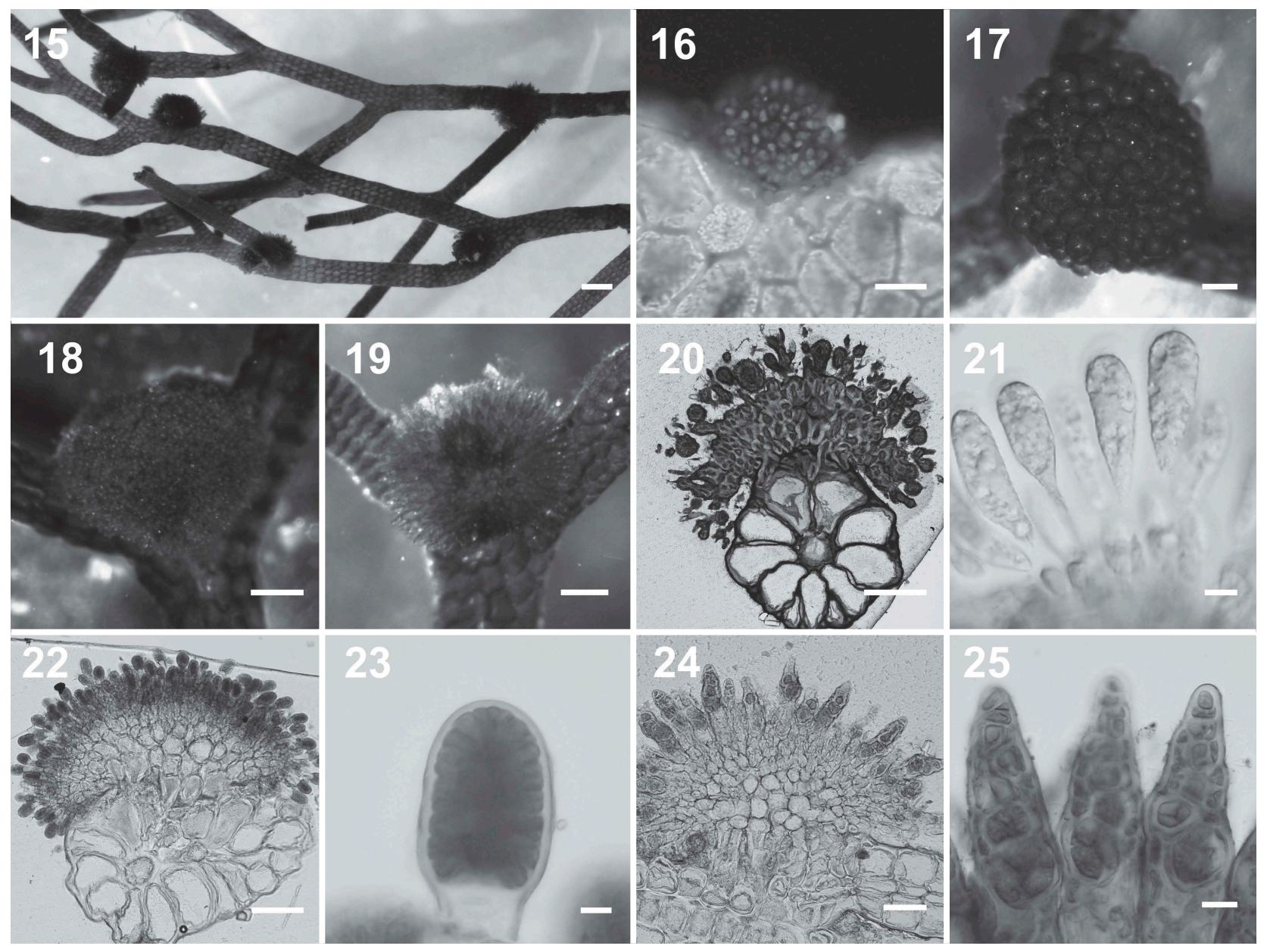

Figs 15-28. Vegetative and reproductive structures of Vertebrata aterrimophila on its host Vertebrata aterrima. Fig. 15. Highly infected host thallus, parasites often found in host branch angles. Fig. 16. Slight autofluorescence in a young parasite was detectable. Fig. 17. Female gametophytes with many smooth spheres (cystocarps) of similar size. Fig. 18. Male gametophyte of a roundish cushion with roundish tips (spermatangial stichidia). Fig. 19. Tetrasporophyte with pointy branch tips (tetrasporangial stichidia). Fig. 20. Female gametophyte with cystocarps over its surface. Resin-embedded transverse section. Fig. 21. Elongated carpospores. Squash preparation. Fig. 22. Male gametophytes covered with spermatangial branches. Resin-embedded transverse section. Fig. 23. Spermatangial stichidum with clusters of spermatia and lacking sterile apical cells. Squash preparation. Fig. 24. Tetrasporophyte is covered with acute tetrasporoangial stichidia. Resin-embedded transverse section. Fig. 25. Tetrasporangium contain tetrahedrally divided tetraspores in a spiral arrangement. Squash preparation. Scale bars: Fig. 15, $400 \mu \mathrm{m}$, Fig. 16, $50 \mu \mathrm{m}$, Figs 17-20, 22, $200 \mu \mathrm{m}$, Figs 21, 23, $10 \mu \mathrm{m}$, Fig. 24, $100 \mu \mathrm{m}$, Fig. 25, $20 \mu \mathrm{m}$.

aterrima, support its recognition as a new parasite species.

The unique developmental characteristic of $V$. aterrimophila is a prominent 'trunk-like' cell from which all parasite connections form, via secondary pit connections, to host cells. Most parasites have a rhizoidal filament fusing with underlying host cells (Nonomura, 1979; Goff \& Coleman, 1987; Goff \& Zuccarello, 1994). Other parasites have several parasite cells within the host thallus which fuse with several host cells (Goff \& Coleman, 1985). Only the parasite Dawsoniocolax bostrychiae uses the initial germination tube, and later rhizoidal filaments, derived from the external parasite body, to connect to underlying host cells (Zuccarello \& West, 1994a). The differences in when and which cell initially connects (e.g. internal parasite cell, germination tube, rhizoidal filaments), via secondary pit connections, to host cells varies greatly between the few species studied, and further studies might reveal whether other parasites have such a prominent connection cell or even new developmental pathways.

From the currently known developmental patterns V. aterrimophila and Dawsoniocolax bostrychiae are the only two parasites growing mainly superficially, which leads to other similarities between these two parasites (Zuccarello \& West, 1994a). For example, host cells are not found immersed in either of these two parasite thalli (our study, Zuccarello \& West, 1994a). All other red algal parasites grow at least partially endophytically, often with deep penetration by parasite cells, leading to embedded host cells in parasite thalli (Goff, 1976; Nonomura, 1979; Goff \& Coleman, 1987; Goff \& Zuccarello, 1994). Shared 
developmental patterns between parasites might led to classifications based on these patterns that overrate similarities.

The only similarity between the development of all red algal parasites are secondary pit connections to their hosts during their early development, but these connections differ in their impacts on host cells. Secondary pit connections are used to transfer parasite nuclei into the host cell (Goff \& Coleman, 1985), and infected host cells with parasite nuclei are altered ('host cell transformation') (Goff \& Coleman, 1985; Goff \& Zuccarello, 1994; Preuss et al., 2017). Host cell transformation varies from few host cell changes caused by the parasites Bostrychiocolax australis, Dawsoniocolax bostrychiae, Leachiella pacifica and Vertebrata aterrimophila (our study; Goff \& Coleman, 1985; Zuccarello \& West, 1994a), to extreme host cell changes (e.g. heterokaryon syncytium) caused by the parasites Gracilariophila oryzoides and Gardneriella tuberifera (Goff \& Zuccarello, 1994). After nuclei transfer, morphological and physiological changes were observed in infected host cells; including an increase of carbohydrates (Nonomura, 1979; Goff \& Coleman, 1987; Goff \& Zuccarello, 1994), cell size 'hypertrophy' (Goff \& Coleman, 1987; Zuccarello \& West, 1994a), and increased cell wall thickness (Nonomura, 1979; Goff \& Coleman, 1987). In our study, we observed apparent increases in carbohydrate concentrations and nuclei size and structural changes in the infected host cells.

Previous developmental studies were able to distinguish between transferred parasite and host nuclei in host cell. Differences in relative DNA contents were used to distinguish transferred parasite nuclei and host nuclei in infected host cells (Goff \& Coleman, 1987). In the case of the parasite Bostrychiocolax australis, transferred parasite nuclei in host cells differed in size from host nuclei in infected host cells (Zuccarello \& West, 1994a). In our study, all observed nuclei in infected host cells increased in size, and parasite and host nuclei could not be distinguished from each other. We do not know if the transferred parasite nuclei might increase in size in host cells, or if only a few parasite nuclei are being transferred and were overlooked.

Mitochondrial marker (cox1) shows that the parasite Vertebrata aterrimophila is genetically similar to, and shares a common origin with, its host Vertebrata aterrima. Many red algal parasites in the Ceramiales show a close host-parasite relationship (Goff et al., 1997; Zuccarello et al., 2004; Kurihara et al., 2010; Preuss \& Zuccarello, 2018). Previous morphological descriptions placed many parasites in independent parasitic genera (Kraft \& Abbott, 2002; Kim \& Cho, 2010), due to their obvious morphological differences from their hosts (e.g. small size). Phylogenetic analyses have shown that most parasites should be placed in the genus of its closest relative, often its host $(\mathrm{Ng}$ et al., 2014; Preuss \& Zuccarello, 2014, 2018).While many vegetative characters of the host genus are not found in the parasite (e.g. rhizoid type, pericentral cells), the reproductive characters support the molecular placement of the parasite within the host genus Vertebrata.

Based on the few known developmental studies, a link was made between development pattern and parasite-host relationships. In closely related parasites ('adelphoparasites') there is greater host cell transformation, including spread to neighbouring cells via infected host cells, than there is between more distantly related parasite-host combinations ('alloparasites') (Blouin \& Lane, 2012; Salomaki \& Lane, 2014; Freese \& Lane, 2017). This simplified classification of parasites as having 'adelphoparasite' and 'alloparasite' developmental patterns does not hold true. In $V$. aterrimophila, minimal host cell changes were observed, similar to other parasites that are closely related to their hosts such as Bostrychiocolax australis (Zuccarello \& West, 1994a) and Janczewskia morimotoi (Nonomura, 1979). The phylogenetic relationship of these parasites to their hosts does not reflect host cell transformation and these hypotheses may be oversimplifications that do not reflect the variation of developments. Further studies combining developmental studies and phylogeny, especially of parasites that parasitize other orders within the Florideophyceae, are needed and additional knowledge about these parasites might help us understand their success and evolutionary trends.

Although red algal parasites are classified as parasites, host nutrient dependency has rarely been demonstrated. The majority of red algal parasites are pigmented (Preuss et al., 2017) and $V$. aterrimophila is another example of a pigmented parasite. Our study showed that $V$. aterrimophila sometimes demonstrated faint auto-fluorescence, which might indicate a degree of photosynthetic ability. Nutrient transport from a host to the unpigmented parasite has been reported (Evans et al., 1973; Harlin, 1973; Goff, 1979). The degree of pigmentation and nutrient dependency was correlated in parasitic plants, where unpigmented species are fully host nutrient dependent (Westwood et al., 2010) and pigmented parasitic plants show a decreased host nutrient dependency, and in some cases even the ability to photosynthesis independently (Tesitel et al., 2010). The few studies in red algal parasites have shown that parasites seem to gain nutrients from their hosts, but the extent of host nutrient dependency needs further investigation to include quantifying the amount of nutrients gained by the parasite, the impact of the lost nutrients on the host and the ability of pigmented parasites to photosynthesize. This 
information will help to establish the case for parasitic status.

Parasitic species are thought to have patchy distributions, which may be associated with different factors. Generally, the majority of potential host populations within a species are uninfected and there are a few highly infected host populations (Poulin, 2013). Patchy distribution in parasites can be influenced by host susceptibility (Poulin, 2013), and variation in host susceptibility to red algal parasites infection is known in hosts (Zuccarello \& West, 1994a, b). Patchy distribution was also observed in the parasite $V$. aterrimophila with one local host population being infected, and only a few other infected hosts collected or observed on vouchers. The majority of red algal parasites only grow on one or two host species (Preuss et al., 2017) but it is not completely known why different populations within a host species are being parasitized and others not.

In summary, this developmental study documents a new early developmental pathway for a red algal parasite with localized infection, superficial growth and a prominent 'trunk-like' cell. Developmental patterns in red algal parasites are varied, as are the phylogenetic relationships to their hosts. Further studies are needed before any generalization can be made. In particular the parasites' nutritional requirements and nutritional independence from their hosts needs further study.

\section{Acknowledgements}

We thank Wendy Nelson and Roberta D'Archino for access to their microscope facility, Te Papa for access to their herbarium and Andrea Glockner-Fagetti for collection support.

\section{Disclosure statement}

No potential conflict of interest was reported by the authors.

\section{Supplementary information}

The following supplementary material is accessible via the Supplementary Content tab on the article's online page at https://doi.org/10.1080/09670262.2018.1536284

Supplementary table S1. Samples used for phylogenetic analysis.

Supplementary table S2. Te Papa vouchers of Vertebrata aterrimophila on its host Vertebrata aterrima from New Zealand, arranged north to south.

\section{Author contributions}

M. Preuss: original concept, collecting and analysing samples, drafting and editing manuscript; G.C. Zuccarello: original concept, editing manuscript.

\section{ORCID}

Maren Preuss (D) http://orcid.org/0000-0002-8147-5643

Giuseppe C. Zuccarello (D) http://orcid.org/0000-00030028-7227

\section{References}

Blouin, N.A. \& Lane, C.E. (2012). Red algal parasites: models for a life history evolution that leaves photosynthesis behind again and again. BioEssays, 34: 226-235.

Díaz-Tapia, P., Maggs, C.A., West, J.A. \& Verbruggen, H. (2017). Analysis of chloroplast genomes and a supermatrix inform reclassification of the Rhodomelaceae (Rhodophyta). Journal of Phycology, 53: 920-937.

Evans, L.V., Callow, J.A. \& Callow, M.E. (1973). Structural and physiological studies on the parasitic red alga Holmsella. New Phytologist, 72: 393-402.

Feldmann, J. \& Feldmann, G. (1958). Recherches sur quelques Floridées parasites. Revue Générale de Botanique.

Freese, J.M. \& Lane, C.E. (2017). Parasitism finds many solutions to the same problems in red algae (Florideophyceae, Rhodophyta). Molecular and Biochemical Parasitology, 214: 105-111.

Goff, L.J. (1976). The biology of Harveyella mirabilis (Cryptonemiales; Rhodophyceae). V. Host responses to parasite infection. Journal of Phycology, 12: 313-328.

Goff, L.J. (1979). The biology of Harveyella mirabilis (Cryptonemiales, Rhodophyceae). VII. Structure and proposed function of host-penetrating cells. Journal of Phycology, 15: 87-100.

Goff, L.J. (1982). Symbiosis and parasitism: another viewpoint. BioScience, 32: 255-256.

Goff, L.J. \& Coleman, A.W. (1984). Transfer of nuclei from a parasite to its host. Proceedings of the National Academy of Sciences USA, 81: 5420-5424.

Goff, L.J. \& Coleman, A.W. (1985). The role of secondary pit connections in red algal parasitism. Journal of Phycology, 21: 483-508.

Goff, L.J. \& Coleman, A.W. (1987). Nuclear transfer from parasite to host. In Endocytobiology, Vol. 3 (Lee, J.J. \& Fredrick, J.F., editors), 402-423. New York Academy of Sciences, New York.

Goff, L.J. \& Zuccarello, G. (1994). The evolution of parasitism in red algae - cellular interactions of adelphoparasites and their hosts. Journal of Phycology, 30: 695-720.

Goff, L.J., Moon, D.A., Nyvall, P., Stache, B., Mangin, K. \& Zuccarello, G. (1996). The evolution of parasitism in the red algae: molecular comparisons of adelphoparasites and their hosts. Journal of Phycology, 32: 297-312.

Goff, L.J., Ashen, J. \& Moon, D. (1997). The evolution of parasites from their hosts: a case study in the parasitic red algae. Evolution, 51: 1068-1078.

Harlin, M.M. (1973). Transfer of products between epiphytic marine algae and host plants. Journal of Phycology, 9: 243-248.

Haupt, A.W. (1930). A gelatin fixative for paraffin sections. Stain Technology, 5: 97-98.

Kearse, M., Moir, R., Wilson, A., Stones-Havas, S., Cheung, M., Sturrock, S., Buxton, S., Cooper, A., Markowitz, S., Duran, C., Thierer, T., Ashton, B., Meintjes, P. \& Drummond, A. (2012). Geneious Basic: an integrated and extendable desktop software platform for the organization and analysis of sequence data. Bioinformatics, 28: 1647-1649. 
Kim, M-K. \& Cho, G-Y. (2010). A new red algal parasite, Symphyocolax koreana gen. et sp. nov. (Rhodomelaceae, Ceramiales), from Korea. Algae, 25: 105-113.

Kraft, G.T. \& Abbott, I.A. (2002). The anatomy of Neotenophycus ichthyosteus gen. et sp. nov. (Rhodo melaceae, Ceramiales), a bizarre red algal parasite from the central Pacific. European Journal of Phycology, 37: 269-278.

Kugrens, P. (1982). Leachiella pacifica, gen. et sp. nov., a new parasitic red alga from Washington and California. American Journal of Botany, 69: 306-319.

Kurihara, A., Abe, T., Tani, M. \& Sherwood, A.R. (2010). Molecular phylogeny and evolution of red algal parasites: a case study of Benzaitenia, Janczewskia, and Ululania (Ceramiales). Journal of Phycology, 46: 580-590.

Mamoozadeh, N.R. \& Freshwater, D.W. (2011). Taxonomic notes on Caribbean Neosiphonia and Polysiphonia (Ceramiales, Florideophyceae): five species from Florida, USA and Mexico. Botanica Marina, 54: 269-292.

Ng, P.K., Lim, P.E. \& Phang, S.M. (2014). Radiation of the red algal parasite Congracilaria babae onto a secondary host species, Hydropuntia sp. (Gracilariaceae, Rhodophyta). PLoS ONE, 9: e97450.

Nonomura, A.M. (1979). Development of Janczewskia morimotoi (Ceramiales) on its host Laurencia nipponica (Ceramiales, Rhodophyceae). Journal of Phycology, 15: 154-162.

Poulin, R. (2013). Explaining variability in parasite aggregation levels among host samples. Parasitology, 140: 541-546.

Preuss, M. \& Zuccarello, G.C. (2014). What's in a name? Monophyly of genera in the red algae: Rhodophyllis parasitica sp. nov. (Gigartinales, Rhodophyta); a new red algal parasite from New Zealand. Algae, 29: 279-288.

Preuss, M. \& Zuccarello, G.C. (2018). Three new red algal parasites from New Zealand: Cladhymenia oblongifoliaphila sp. nov. (Rhodomelaceae), Phycodrys novae-zelandiaephila sp. nov. (Delesseriaceae) and Judithia parasitica sp. nov. (Kallymeniaceae). Phycologia, 57: 9-19.

Preuss, M., Nelson, W.A. \& Zuccarello, G.C. (2017). Red algal parasites: a synopsis of described species, their hosts, distinguishing characters and areas for continued research. Botanica Marina, 60: 13-25.

Reinsch, P.F. (1875). Contributiones ad algologiam et fungologiam. T. O. Weigel, Lipsiae.
Ronquist, F. \& Huelsenbeck, J.P. (2003). MrBayes 3: Bayesian phylogenetic inference under mixed models. Bioinformatics, 19: 1572-1574.

Salomaki, E.D. \& Lane, C.E. (2014). Are all red algal parasites cut from the same cloth? Acta Societatis Botanicorum Poloniae, 83: 369-375.

Saunders, G.W. (2005). Applying DNA barcoding to red macroalgae: a preliminary appraisal holds promise for future applications. Philosophical Transactions of the Royal Society B: Biological Sciences, 360: 1879-1888.

Setchell, W.A. (1918). Parasitism among the red algae. Proceedings of the American Philosophical Society, 57: 155-172.

Stamatakis, A. (2006). RAxML-VI-HPC: maximum likelihood-based phylogenetic analyses with thousands of taxa and mixed models. Bioinformatics, 22: 2688-2690.

Sturch, H.H. (1926). Choreocolax polysiphoniae, Reinsch. Annals of Botany, 40: 585-605.

Tesitel, J., Plavcova, L. \& Cameron, D.D. (2010). Interactions between hemiparasitic plants and their hosts. Plant Signaling and Behavior, 5: 1072-1076.

Westwood, J.H., Yoder, J.I., Timko, M.P. \& Depamphilis, C.W. (2010). The evolution of parasitism in plants. Trends in Plant Science, 15: 227-235.

Yang, E.C., Boo, S.M., Bhattacharya, D., Saunders, G.W., Knoll, A.H., Fredericq, S., Graf, L. \& Yoon, H.S. (2016). Divergence time estimates and the evolution of major lineages in the florideophyte red algae. Scientific Reports, 6: 21361.

Zuccarello, G.C. \& Lokhorst, G.M. (2005). Molecular phylogeny of the genus Tribonema (Xanthophyceae) using $r b c \mathrm{~L}$ gene sequence data: monophyly of morphologically simple algal species. Phycologia, 44: 384-392.

Zuccarello, G.C. \& West, J.A. (1994a). Comparative development of the red algal parasites Bostrychiocolax australis gen. et sp. nov. and Dawsoniocolax bostrychiae (Choreocolacaceae, Rhodophyta). Journal of Phycology, 30: 137-146.

Zuccarello, G.C. \& West, J.A. (1994b). Host specificity on the red algal parasites Bostrychioclax australis and Dawsoniocolax bostrychiae (Choreocolacaceae, Rhodophyta). Journal of Phycology, 30: 762-473.

Zuccarello, G.C., Moon, D. \& Goff, L.J. (2004). A phylogenetic study of parasitic genera placed in the family Choreocolacaceae (Rhodophyta). Journal of Phycology, 40: 937-945. 